\title{
REGENERATING INDIA'S FORESTS: RECONCILING GENDER EQUITY WITH JOINT FOREST MANAGEMENT
}

\section{Madhu Sarin}

\section{INTRODUCTION'}

In India 'scientific' forest management has historically represented the usurpation of forest dwellers' rights over their lands and forests by the state. The resulting disempowerment and displacement of indigenous tribal and hill communities, and the devaluation and disintegration of their community centred cultural and resource management traditions has been well documented (Guha 1991; Gadgil and Guha 1992; Kelkar and Nathan 1991; Fernandes and Menon 1987). In this context, the recent policy shift towards joint forest management (JFM) by several states is a belated, but welcome, first step towards reducing the gross inequities in access to forest resources embodied in past forest management policies.

Among its basic objectives the National Forest Policy, 1988 emphasizes 'meeting the requirements of fuelwood, fodder, minor forest produce and small timber of the rural and tribal populations' and 'creating a massive people's movement, with the involvement of women, for achieving these objectives $^{2}$ (GOI 1988).

As of late 1994, 15 state governments ${ }^{3}$ have issued Joint Forest Management resolutions specifying the basis of JFM partnerships with local communities. Between them, these 15 states have 74.6 per cent of the country's 75 million hectares of public forest land and 91 per cent of the country's tribal population, whose symbiotic relationship with forests is well known. By mid 1992, more than 1.5 million hectares of forest land were already being protected by villages through more than 10,000 community institutions (CIs) in 10 states of India (Singh and Khare 1993). Implementation of JFM has been most extensive in West Bengal.

There are also dangers. Dependence on forest resources differs greatly between individuals in terms of tribe, caste and class and between and within communities and households by gender and age.

${ }^{1}$ This is a shortened version of a paper presented at the International Workshop on India's Forest management and Ecological Revival, New Delhi, India, 10-12 February 1994.

${ }^{2}$ Emphasis added.
Even under JFM, forest protection per se may get placed on a pedestal and 'people's participation' become equated with the more powerful and less forest-dependent villagers taking on the forest department's traditional policing role against the more dependent women and men.

Furthermore, most JFM resolutions include provisions for sharing income between the states and local institutions or their individual members. JFM thus implies a new regime of property rights - not to the forest land but to its management and produce. Issues of equity in JFM need to be given far greater attention in this respect. Both the nature of entitlements specified in JFM partnerships and the decision making processes by which management priorities are defined will have far reaching consequences in terms of equity between communities, within communities and by gender and age within households.

This article looks at how JFM in its present phase is dealing with the least addressed issue of gender equity. The household is taken as the unit of participation at the community level. JFM is effectively equating people's participation with men's participation because of its assumption that as 'heads of households' men adequately represent the interests of all household members. By overlooking gender differences in the distribution of responsibilities and access to resources for survival within households, JFM may end up further disempowering tribal and other poor women as most past development interventions have done.

\section{WOMEN AND FORESTS}

Rural, particularly tribal, women are major actors in India's forestry sector. They have traditionally gathered a wide range of non-timber forest products (NTFPs) for both subsistence and income generation through processing and sale. In addition, they participate as wage labour in forestry works. Women's

\footnotetext{
${ }^{3}$ Andhra Pradesh, Bihar, Gujarat, Haryana, Himachal Pradesh, Jammu and Kashmir, Karnataka, Madhya Pradesh, Maharashtra, Orissa, Punjab, Rajasthan, Tripura, West Bengal and Tamil Nadu.
} 
role as gatherers includes the collection of firewood for sale and self consumption, fodder for livestock and other NTFPs including food, medicines, seeds, leaves, and building materials. In 1986, NTFPs accounted for 'nearly two fifths of forest department revenue and three fourths of net export earnings from forest produce' (Commander 1986). Indeed, women - particularly tribal women - are the majority of workers involved in the NTFP economy. About 70 per cent of NTFP collection takes place in the central tribal belt in the five states of Maharashtra, Madhya Pradesh, Bihar, Orissa and Andhra Pradesh (World Bank 1991).

Most of women's employment is in small-scale enterprises using NTFPs as raw material, including activities such as rope making from different types of grasses, basket making, tasar silk cocoon rearing, lac cultivation, making products from bamboo and oil extraction. Two of the main cash earners among NTFPs, sal seeds and tendu leaves, are collected primarily by women. Table 1 gives information on use of NTFPs in a village in West Bengal as illustration.

Since availability of NTFPs is seasonal, these activities do not provide employment through the year. Compounding this situation is the decreased availability of NTFPs as a result of deforestation. The combined result of these, and the lack of other regular employment opportunities or sources of income, has given rise to year round harvesting of firewood for sale. Headloading, as this activity is called, is the largest single source of employment in the energy sector in India (CSE 1985). Most headloaders are women.

Extensive field surveys confirm women's continuing dependence on NTFPs for income and subsistence. They also indicate that women receive abysmally low returns for their labour and that between 20 to 60 per cent are the sole earners in their households (G.O.I. 1988). As JFM attempts to convert open access public forest lands into common property resources managed in partnership with local community institutions, it needs to develop concrete strategies to ensure both that women's traditional rights of access are not undermined and that they are equally empowered to participate in their management on the basis of clear rights of access and control over benefits.

However, promoting women's equal and active participation in community institution decision making has to deal with the cultural constraint of their having been excluded from such forums by tradition. Although the status of tribal women differs from region to region, they generally enjoy a better status than women in mainstream Indian society. In the traditional forest-centred tribal economies, women's important role as gatherers of forest foods and subsistence goods made them economically strong and valued members of the community. This is also reflected in the tradition of bride price instead of dowry prevalent among most tribal communities. Until today, women's right to control their income from produce gathered from common lands is generally respected, although it is under threat of rapid erosion. In contrast, income from privatized agricultural land, which passes through male lineages, is strictly considered the income of the male owner even if women contribute substantial parts of the labour for its cultivation (Kelkar and Nathan 1991).

Even for tribal women, however, there have been two crucial areas of inequality: property rights and political participation. Among the Jharkhand tribes of Eastern India, for instance, property, particularly land, passes through the male lineage and under customary law women do not have inheritance rights to land. In the political domain the traditional village assembly (panchayat) is virtually an all-male institution. Membership normally comprises male heads of households and women are provided access only under highly exceptional circumstances (Kelkar and Nathan 1991).

\section{CURRENT STATUS OF JFM IN THE COUNTRY}

In Central and Eastern India, where community forest protection is beginning to take place on a relatively large scale, there are two clearly discernible patterns. One consists of areas where the state government has actively encouraged local villages to protect forests on the assurance of tangible benefits in return. West Bengal is the outstanding example. The other pattern consists of people initiating forest protection on their own, often with little or no involvement of the state forest department, and without the 'incentive' of a promised share of income from the regenerated produce. Normally the state gives them formal recognition as VFMPS (Village Forest Management and Protection Samitis). Such self-initiated forest protection is taking place on a significant scale in Orissa and Bihar and to a lesser 
Table 1: Seasonal collection of major NTFPs and their use

Village Karapara, Ranibandh Range, Bankura South Division, West Bengal ${ }^{4}$

$\begin{array}{ll}\text { Month } & \text { Name of NTFP } \\ \text { January } & \text { amla, harra, behera, bhiri kumra, sal patta } \\ \text { February } & \text { sal patta } \\ \text { March } & \text { mahua flower, piyal fruit } \\ \text { April } & \text { mahua flower, kendu patta, piyal fruit } \\ \text { May } & \text { kendu patta, mahua seed, piyal fruit } \\ \text { June } & \text { neem and kusum seed, mahua seed } \\ \text { July } & \text { neem and kusum seed, chatu, sal patta, mahua seed } \\ \text { August } & \text { chatu, kalmegh, anantomul, ban-rasson, sal patta } \\ \text { September } & \text { chatu, sal patta } \\ \text { October } & \text { sal patta } \\ \text { November } & \text { pania lata, sal patta } \\ \text { December } & \text { kalmegh, anantomul, ban-rasson, bhuri kumra, sal patta }\end{array}$

The majority of NTFPs are collected by women only. The exception is mahua flower and seed which are collected by both men and women. Women keep the income from their gathering activities.

mahua flower and seed: These are the two most important NTFPs for women. A portion of the collected mahua flower is consumed as food and liquor, and the rest sold. The flower fetches fis. 6 per $\mathrm{kg}$ and, on average, a household can collect three quintals ${ }^{5}$ per season. Each household can collect up to one quintal of mahua seed per season which fetches As. 8 per $\mathrm{kg}$. Mahua seed oil is partly sold and partly kept for home consumption.

sal patta: Salleaf plates sell at Rs.2.50 per 100 plates. With protection, trees grow to greater heights and salleaf collection becomes difficult. However, fallen leaves are used as cooking fuel. A woman can earn up to Rs. 10 for a full days work. Demand for leaf plates is seasonal, mostly confined to January to June.

sal seeds: One $\mathrm{kg}$ of sal seeds are exchanged for $1.5 \mathrm{~kg}$ of salt. Usually women get $20 \mathrm{~kg}$ of salt in exchange for collecting about $13 \mathrm{~kg}$ of sal seeds in their spare time over 10 days. Women can collect up to $4-5 \mathrm{~kg}$ of sal seed in about two hours. For eight hours work (collecting and threshing) women can earn Rs. 15.

kendu patta: Kendu patta is collected from both private and forest land. It is sold at a rate of Rs. 10 for 2,000 leaves (i.e. Rs. 0.10 for a bundle of 20 leaves). When leaves are abundant women can earn up to Rs. 40 per day, which includes collection, sorting and tying the leaves. At other times they eam about Rs.25-30 per day. During the short season (1.5 months), woman can earn up to Rs.1,000.

medicinal plants: kalmegh, anantomul, ban-rasson are used to treat cattle; bhuri kumra is good for treating blood sugar; amla, harra and behera are collected mostly for household consumption.

neem and kusum seeds: Oil is extracted from these seeds and used for domestic consumption.

pania lata: This is a creeper sold at Rs. 1 per foot. It is used as a dye.

chatu (mushrooms): These are collected for domestic consumption and also sold in the market. Women spend about an hour per day collecting chatu and, per season, collect a total of $8-10 \mathrm{~kg}$. At Jhilimili, mushrooms sell for Rs. 20 per kg, while at Bankura they can fetch Rs. 35 per kg. There are eight local varieties of chatu. 
extent in Gujarat, Rajasthan, Karnataka, Madhya Pradesh, Andhra Pradesh and some other states.

These community groups, the majority with traditionally exclusive male membership and leadership, are attempting to regenerate their forests to deal with the hardship and scarcities resulting from forest degradation. ${ }^{6}$ While some of these groups have emerged organically and have functioned for decades, others are relatively new. Their community organizations vary in size from a hamlet of a few households to numerous villages comprising thousands of families. They also differ in their structures and methods of functioning. But their stability and effectiveness is almost always rooted in equitable sharing of costs and benefits among members, consensus-based decision making and the capacity to enforce agreed access rules, primarily through social pressure and control.

In the case of the self-initiated groups, given the cultural traditions of women's exclusion from community affairs, 'community' organizations have essentially been organizations comprising male membership. Women's role, if any, seems to have been that of passive acceptors of male group decisions. There has been little effort to change their exclusive male mode of functioning after formalization. An indication of such groups' attitudes towards women's participation is evident from a number of case studies. In a study of two self-initiated forest protection groups in Orissa, it was found that in one, women were not allowed to attend general body meetings even when they were a part of the dispute being discussed. In the second case, women's participation was found to be non-existent (Pati et al. 1993).

In the case of FD promoted JFM groups, again, by and large, it has been an all male affair. The almost 100 per cent male staffing of most forest departments, and the greater ease with which village men can be assembled, results in men interacting with men to take decisions on behalf of the 'community'. Even where some state JFM resolutions have specified the inclusion of women members in the general body or the executive committee of a forest protection committee (FPC), women have been members in name only, having no active participation in decision making and no input into the articulation of priorities. The potential differential impact of forest protection on women through such 'community' organizations is discussed below.

\section{IMPACTS OF FOREST PROTECTION ON WOMEN: EVIDENCE FROM THE FIELD}

One of the first and immediate costs of community forest closure is the partial or total loss of availability of firewood from the area. In India's forested regions, barring small exceptions, procuring firewood is culturally defined as women's responsibility. Firewood scarcity and women's increasing hardship in gathering it dominated forest policy discussions during the 1980s; large social forestry projects were launched to increase firewood availability and macro-level policy analysis continued to highlight the huge gaps in supply and demand. Yet there has been a remarkable silence on how JFM is addressing the problem and how women members of forest protection groups are procuring cooking fuel after forest closure.

Undoubtedly, the nature and extent of the impact of closure on women will vary depending on alternatives available locally. However, hacking trees, bushes and even pulling out roots by predominately female headloaders in search of cooking fuel has been identified as a major cause of forest degradation. Stopping this extraction can only be possible if a viable alternative is made available to these women. What alternatives is JFM offering to women in such areas both in the short and long-term? Excepting for notablecases such as Harda forest division in Madhya Pradesh where supplies are stated to have increased four fold through management inputs (Singh and Khare 1993) or the periodic 'lumpy' supplies from thinning operations on coppicing species in some areas, little has been said about devising either short or long-term alternatives through forest management interventions.

Recent field investigations of a number of selfinitiated and officially supported forest protection groups in Gujarat, West Bengal and Bihar provide disturbing indications of the nature of impact of the resulting firewood scarcity on women.

In the Santrampur area of Panchmahals district in Gujarat, 30 to 40 villages started protecting their

\footnotetext{
6 Where rootstock remains, regeneration as opposed to outright reforestation is generally a viable strategy.
} 
forests entirely on their own initiative from the mid1980s onwards. The decision in each case was taken during traditional male gatherings to discuss community affairs. The men discussed the non-availability of timber for house construction and agricultural implements due to forest destruction and decided to close their forests to facilitate regeneration of teak from the surviving rootstock. Two to three men were assigned protection duties by each group and every household was asked to contribute $10 \mathrm{kgs}$ of grain per year to compensate them. Entry in the protected areas with any kind of tools was totally banned. Now only dry and fallen twigs and branches can be collected as cooking fuel. After three to five years of such total closure, some of the groups have started opening their forests for cutting bushes and multiple shoots for only one or two days per year for firewood. When asked where firewood was now obtained, the male leaders were dismissive and said that all households had private lands. Asked about the women's reactions to forest closure, they said that if any woman was caught violating the rules, the man of her household was reprimanded. The men's determination and discipline appeared to be an inspiring example of community forest protection.

A separate meeting with the women of some of the groups, however, revealed a rather disturbing picture. They said that now they had to walk between one to five extra hours (depending on the location of their village) for each headload of firewood which they obtained from a yet unprotected forest area at considerable distance. The men had not consulted the women about their decision to close the forest. When asked if they had protested, the women replied that if they didn't comply, they would be 'beaten with thick, heavy sticks' by their men.

While the men had ably taken care of their responsibility for providing timber for the household, they had started policing women from within the home, where they are most vulnerable and least able to fight back. The women had accepted the dramatic increase in their time and labour required for gathering firewood as a necessary evil by rationalizing that 'every household needs timber for house construction and agricultural implements'. But households also require fuel for eating cooked food. While timber is needed once in a few years, cooking fuel is required with relentless regularity every day.

Similar increases in labour and time required for procuring cooking fuel were revealed by the women of four FPCs visited in January 1994 in South Bankura forest division of West Bengal (see Table 2, next page). The problem of cooking fuel scarcity resulting from forest protection was also evident during discussions with $\mathbf{1 0}$ forest protection groups in South Bihar and has been mentioned in other studies (Raju et al. 1993; Shah and Shah infra). When a large number of villagers were motivated to start forest protection in the Hazaribagh East Division in South Bihar during 1990-91, the sudden scarcity of firewood in the area, particularly in villages with no forest area of their own, had created a situation where there was a danger of riots breaking out. The FD had to rush firewood supplies to its depots to prevent the situation from getting out of hand.

In the Malekpur tree growers' co-operative society (TGCS) participating in JFM in the Sabarkantha district of Gujarat, women had to walk to the still unprotected forest of Jageswari village $10 \mathrm{kms}$ away to collect firewood for two years after protection was initiated by the co-op. Their problem remained 'invisible' to village men, the FD and even the supporting NGO until the latter facilitated a meeting of village women. It was only then that one of the participants mentioned that not only were women now having to spend a whole day collecting one headload of firewood from distant forests, but Vagheswari villagers were accusing them of protecting their forest at the expense of destroying Vagheswari's. In response, cut-back operations were organized in February 1993 by the co-op's progressive chairman and this yielded seven quintals of firewood per household. The co-op plans to repeat this in sections of their forest for the next three years, after which thinning will be started. This will also release some fuelwood for local women. This intervention, combined with women using agricultural residues as fuel, has largely solved Malekpur women's cooking fuel problem, at least in the short-term.

The dominant management model for naturally regenerating JFM areas being promoted at present

\footnotetext{
7 Personal communication, September 1993. Mr A. Kumar was Divisional Forest Officer of Hazaribagh East Division, Bihar Forest Department in 1990-91 when the above situation developed.
} 


\section{Table 2: Impacts of 'participatory' forest protection on women's responsibility for procuring cooking fuel}

Village

Time/Distance for
Gathering One
Headload
Before After
Protection Protection

Frequency of

Other Impact

Collection

Protection Protection

WEST BENGAL (Bankura South Division)
1. Kamardanga $\quad 1.5$ to 2 hrs 4 to 5 hrs
5 days/wk except monsoons
Partial switching to lantana,
2. Bhadli
$0.5 \mathrm{~km}$
4 to $5 \mathrm{~km}$
N.A.
painful to collect.

$\begin{array}{llll}\text { 3. Barapaccha } & 1 \text { to } 2 \text { hrs } & 3 \text { to } 4 \text { hrs } & \begin{array}{l}\text { Daily, except } \\ \text { monsoons }\end{array} \\ \text { 4. Karapara } & 0.5 \mathrm{~km} & 8 \text { to } 9 \mathrm{kms} & \text { N.A. }\end{array}$
Have to 'steal' from other's forest, hefty fines if caught. Combined firewood collection with forest protection.
Partial switching to leaves, dung, husk, weeds.

GUJARAT (Panchmahals district)
1. Vena
0.5 hrs
3 to $4 \mathrm{hrs}$
1 week/month

Harassment andabuse by FD staff and other villagers when go to unprotected forest area further away.
2. Chari
$1 \mathrm{hr}$
4 to 5 hrs
Daily for one monthlyear
Abuse by other villagers, fear
3. Malekpur*
1 to 2 hrs
Whole day
N.A.
(Sabarkantha
district) of being beaten by own men.
Abuse by residents of other village from whose forest collected firewood.

\section{SOUTH BIHAR**}
1. Saraiya
(Palamau district)

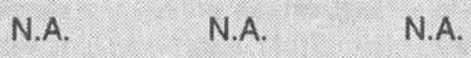
2. Ramua
(Hazaribagh
district)

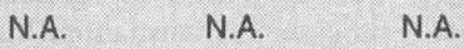
3. Banaso
(Hazaribagh
district)

(Entry to protected area was totally banned for first five years)
Switching to leaves, dung, lantana, arhar sticks, some purchasing firewood.

Switched to leaves, lantana, dung, thorny bushes, some buying coal.

Switched to dung, weeds.

Source: Information collected by author during field visits (West Bengal, January 5-6, 1994; Gujarat, December 1993; Bihar, September 1993).

* In Malekpur village this situation prevailed for the first two years of protection until, in a meeting facilitated by an NGO, women pointed out their increased hardship. This led to the chairman of the co-operative initiating cut-back operations. This has considerably reduced the problem.

** Due to the poor quality of soil for agricultural production in the Chota Nagpur plateau of South Bihar, a major reason why villagers keep livestock is to obtain dung for fertilizing their fields. In such areas, switching to dung to use as fuel is likely to have a negative impact on the already low agricultural yields. 
will have to be changed. If the major objective of community protection is to generate income from harvesting poles or timber, then, with time, firewood output from such lands will decline. For example, a regenerating sal forest managed according to standard silvicultural practices will generate some firewood in lumps in the 1st, 4 th and 7 th years through coppicing, multiple shoot cutting and thinning operations, but after that the trees will not yield any firewood until the final harvest. Villages endowed with large forest areas could maintain yearly flows of firewood by carrying out these operations on smaller patches in rotation. But this will not be feasible in villages with limited per capita forest area. In such cases specific sections of the forest will have to be managed for firewood and poles.

\section{WHY DO 'WOMEN OFFENDERS' CONTINUE TO BE A MAJOR PROBLEM DESPITE JFM?}

In different forums, be it of FD officers, NGO representatives or even of village women and men, the most frequently mentioned problem for JFM is that of tackling 'women offenders'. At a workshop on JFM held in Calcutta in November 1993, an officer of West Bengal's FD stated that he would be happy to find ways of increasing women's 'participation' since 90 per cent of forest offenders were women. During a visit to Malekpur TGCS' regenerating forest, male chairmen of 2-3 neighbouring TGCSs also participating in JFM in Sabarkantha district, talked proudly about how they had ruthlessly beaten women firewood gatherers from other villages to stop them from damaging their forest. A literate village woman, from an obviously well off household, demanded that women forest guards be deployed to stop other village women from damaging their protected forest during a meeting in Ramua village in the Hazaribagh district of Bihar in September 1993. Even the dynamic women leaders of Nari Bikas Sangh, a grassroots organization of women committed to women's empowerment in Bankura district of West Bengal, talked about how women FPC members could be more effective in protection as they could 'snatch the axes' of outside women firewood gatherers. In contrast, men could be accused of molestation by the women. The fear of such accusations is repeatedly mentioned by male FD field staff as a major problem when dealing with women forest offenders.

Ironically, many field initiatives of 'successful' women's involvement in JFM (where it was absent earlier) have begun to use local women for tackling outside women offenders without addressing the participating women's forest-related needs more effectively. This has been reported in the case of both self-initiated forest protection groups and officially promoted groups (Viegas and Menon 1993). This approach is worrying because it further reinforces stereotyped images of senseless, undisciplined and destructive women needing to be controlled.

\section{EFFORTS OF FOREST PROTECTION AND NON-FUEL NTFPs}

It is generally assumed that women will benefit from increased income from increased availability of NTFPs in protected forest areas. This assumption may often be mistaken. Ecological changeand changes in the composition of species with forest regeneration indicate that while some NTFPs increase, others decrease with protection. Maintaining steady flows of income or subsistence goods from the more useful species requires management interventions specifically designed for the purpose. Sal and tendu leaves are steady sources of income for women gatherers in Central and Eastern India. The yields of both may decrease rather than increase with protection. Tendu is intolerant of shade from regenerating species. In the case of sal leaves, with an increase in the height of the trees due to protection, leaf availability falls since leaves become inaccessible togatherers. Leaves continue to be available from the multiple shoots around the main regenerating stem, but if these shoots are cut to promote better growth of the main stem for pole production, even this source of sal leaves is lost. However, some firewood becomes available by the same token.

Depending on local socioeconomic realities, some women may prefer short-term increased availability of firewood through cutting or greater availability of sal leaves through the year, while others may prefer to forsake a regular access to income from leaves in favour of delayed income from poles after several years. The resolution of such differences is closely tied to political representation on local JFM committees.

\section{WOMEN'S ENTITLEMENT TO A SHARE OF THE INCOME: AN ANALYSIS OF STATE JFM RESOLUTIONS}

As indicated above, women gatherers are incurring the major costs of forest protection by voluntarily (or involuntarily) forsaking collection of a daily 
necessity such as firewood and, in some cases, reduced income from NTFPs. What share of the eventual income from the timber or pole harvests will they be entitled to receive in return?

The state JFM resolutions provide for two types of arrangements for benefit sharing from final timber harvests between FDs and community institutions. Either the entire cash income or share of the produce goes to a common fund held by the CI, and from which individual members may be able to borrow, or all or a part of it is distributed between individual members.

In this respect, women's rights and entitlements have been almost totally overlooked by most state JFM resolutions. Four out of 15 state JFM resolutions (Bihar, Karnataka, Madhya Pradesh and Tripura) provide for the membership of only one representative per household. This membership criterion effectively excludes women, except widows with no adult sons, from CI membership. Five states (Andhra Pradesh, Himachal Pradesh, Tamil Nadu, Orissa and West Bengal) have attempted to overcome this shortcoming by providing for one male and one female representative per household (in the first four cases) or for 'joint' membership of husband and wife (in West Bengal).

Although a substantial improvement over the one representative per household formula, these provisions still exclude a large number of both women (Sarin 1993) and men. For example, in the case of joint or extended families, such provisions could begrossly inequitable for the younger nuclear families within each larger unit. Furthermore, in many cases, the distribution of shares is still based on the household unit, or has been left to the discretion of the management committee (MC) or an FD officer.

From next year, several hundred FPCs in West Bengal are going to start benefit sharing. The question of who, husband, or wife, or husband and wife jointly, should get the share was posed to the members of three FPCs in South Bankura Division, West Bengal recently. Both women and men were present at these meetings. In all three villages, without any hesitation, all women felt that the shares should be divided equally and given separately to both husband and wife. There was no vote for 'joint accounts' or the husband being more eligible as the 'head of the household'. These women are responsible for a major share of household sustenance and they wanted control over their share of the income.

\section{EMPOWERING WOMEN WITH VISIBILITY AND EQUAL ENTITLEMENTS IN JFM RESOLUTIONS}

To effectively empower local communities to manage forest resources on principles of equity and sustainability, JFM must solicit the active participation of both women and men. Treating women as assumed, passive beneficiaries of decisions taken by (primarily male) 'representatives' of their communities will not only reinforce women's traditional subordination but also transfer to them a disproportionate share of the costs of protection. It will also deprive JFM the benefit of women's rich indigenous knowledge and experience as major users and managers of India's forest resources.

FDs should aim to facilitate the process of women's empowerment by making women aware about their rights, encouraging attendance at meetings and participation in decision making. Moreover, of key importance is to ensure that gender differences in dependence on forests are taken into consideration while designing forest management interventions. Where the formation of new CIs is being promoted by FDs, or even where formal recognition of selfinitiated groups is being granted, the FDs, as instruments of the state, are in the advantageous position of being able to insist on gender equity in an organization's structure and functioning, as follows:

1 Make women's separate identity visible in the general body membership of community institutions by dispensing with using the household as the unit of membership. Using the household as the membership unit can be highly inequitable not only by gender but also by age, particularly in the case of extended or joint family households. As membership is also linked to entitlement to benefits, the only satisfactory provision compatible with the equal rights guaranteed by the Constitution of India is keeping membership open for all adult women and men.

2 Similarly, women's representation in the decision making bodies of the CIs needs to be increased to at least $1 / 3$ rd of the total membership (as provided for the Panchayati $R a j$ institutions by the 73rd Constitutional 
Amendment) and preferably to 50 per cent reflecting their proportion in the population.

3 To ensure that women do not remain meaningless 'names on lists'; and to structure regular access to information and decision making forums for women, the quorums for both general body and MC meetings should include the requirement of $\mathbf{3 0}$ to 50 per cent of those present being women.

4 Wherever there is a provision for distribution

\section{REFERENCES}

Agarwal, Bina, 1989, 'Rural women, poverty and natural resources: sustenance, sustainability and struggle for change', Economic and Political Weekly, 28 October

Chatterjee, Mitali, undated, 'Women in joint forest management: a case study from West Bengal', Technical Paper No 4, Calcutta: IBRAD

Commander, S., 1986, 'Managing Indian forests: a case for the reform of property rights', Development Policy Review Vol 4 No 4: 325-344

CSE, 1985, The State of India's Environment 1984-85: The Second Citizen's Report, New Delhi: Centre for Science and Environment

Fernandes, Walter and Menon, Geeta, 1987, Tribal Women and Forest Economy, Deforestation, Exploitation and Status Change, New Delhi: Indian Social Institute

Gadgil, Madhav and Guha, Ramachandra, 1992, This Fissured Land, An Ecological History of India, Delhi: Oxford University Press

Government of India, 1988, National Forestry Policy Resolution of benefit shares in cash or kind among members, women members' independent entitlements must be clearly specified.

5 Commencement of any forest protection under JFM must be preceded by an analysis of existing dependence on forest produce by gender and socio-economic status combined with clear short and long-term alternatives for meeting the most essential of those needs following closure.
Guha, Ramachandra,1991,The Unquiet Woods: Ecological Change and Peasant Resistance in the Himalaya, Delhi: Oxford University Press

Kelkar, Govind and Nathan, Dev, 1991, Gender and Tribe: Women, Land and Forests in Jharkhand, New Delhi: Kali for Women

Pati,S.,Panda, R. and Rai, A., 1993, 'Comparativeassessment of forest protection by communities', Paper presented at JFM Workshop, Bhubaneswar, 28-29 May

Sarin, M., 1993, 'From conflict to collaboration: local institutions in joint forest management', JFM Working Paper No 14, New Delhi: SPWD/The Ford Foundation

Singh, S. and Khare, A., 1993, 'People's participation in forest management', Wasteland News, Vol VIII No 4

Viegas, P. and Menon, G., 1993, 'Bringing government and people together. forest protection committees in West Bengal - role and participation of women', in A.M. Singh and N. Burra (eds) Women and Wasteland Development, New Delhi: Sage Publications

World Bank, 1991, Gender Poverty in India, Washington DC: IBRD 